\title{
Ocena efektów kosmetycznych radioterapii interwencyjnej (brachyterapii) w świetle doniesień konferencji ESTRO37.
}

\section{Evaluation of cosmetic outcomes of interventional radiotherapy (brachytherapy) in the light of ESTRO37 conference reports.}

\author{
Artur Jan Chyrek ${ }^{1}$
}

${ }^{1}$ Zakład Brachyterapii, Wielkopolskie Centrum Onkologii, Poznań, Polska

\section{Streszczenie}

Na przełomie kwietnia i maja 2018 roku w Barcelonie, w Hiszpanii odbyła się 37 konferencja naukowa Europejskiego Towarzystwa Radioterapii Onkologicznej (ESTRO). W jej trakcie po raz kolejny prezentowany był panel grupy GEC-ESTRO zajmującej się radioterapią interwencyjną (brachyterapią), która polega na bezpośrednim wprowadzeniu izotopu promieniotwórczego w guza lub jego lożę. Artykuł ten ma na celu prezentację doniesień dotyczących efektów kosmetycznych brachyterapii stosowanej u pacjentów nie tylko po to by wyleczyć nowotwór, ale również by pozwolić na zaoszczędzenie narządów, w których jest on zlokalizowany.

\begin{abstract}
At the turn of April and May 2018 in Barcelona, Spain, another 37th scientific conference of the European Society for Oncological Radiotherapy (ESTRO) took place. In the course of the session, a panel of GEC-ESTRO group on brachytherapy - a method of radiotherapy involving the direct introduction of a radioisotope into the tumor or a tumor bed was presented. This article aims to present the reports on the cosmetic effects of brachytherapy used in patients not only to cure cancer, but also to spare the organs in which it is located.
\end{abstract}

Stowa kluczowe: brachyterapia, efekty kosmetyczne,

Keywords: brachytherapy, cosmetic effects

Adres do korespondencji

Artur Jan Chyrek

Zakład Brachyterapii

Wielkopolskie Centrum Onkologii, ul. Garbary 15, 61-866 Poznań, Polska

e-mail: chyrek.artur@gmail.com 


\section{Wstęp}

W przeciwieństwie do teleradioterapii, brachyterapia jest metodą inwazyjną polegającą na wprowadzeniu specjalnych aplikatorów w bezpośrednią okolicę guza lub loży po jego usunięciu. Dzięki temu pozwala ona dokładniejsze dostarczanie skoncentrowanej i często biologicznie wyższej dawki promieniowania do tkanek objętych procesem nowotworowym z jednoczesną ochroną otaczających je tkanek zdrowych [1]. Jak wiadomo tkanki zdrowe w zależności od swojej budowy oraz funkcji mogą odpowiadać na promieniowanie jonizujące odczynami ostrymi lub późnymi, a toksyczność tą możemy mierzyć przy użyciu różnych skal, z których najbardziej rozpowszechnione są RTOG/EORTC (Radiation Therapy Oncology Group and the European Organization for Research and Treatment of Cancer) i CTCAE (Common Terminology Criteria for Adverse Effects). Badanie oraz raportowanie odpowiedzi tkanek zdrowych jest niełatwe nie tylko przez dużą zmienność reakcji na promieniowanie jonizujące w populacji, ale także z powodu wielu ocenianych punktów końcowych, które są określane przez lokalizację anatomiczną leczonego miejsca [2].

Bardzo duża część powikłań radioterapii może mieć wpływ na efekt kosmetyczny występujący po leczeniu - dotyczy to zwłaszcza nowotworów w obrębie twarzy oraz gruczołów piersiowych. To właśnie tych lokalizacji dotyczyły doniesienia prezentowane na konferencji ESTRO.

\section{Rak piersi.}

W trakcie sesji dotyczącej raka gruczołu piersiowego, wykład porównujący efekt kosmetyczny u pacjentek poddanych brachyterapii w porównaniu do tych, które otrzymały samodzielną teleradioterapię prezentowany był przez pierwszego autora dwóch znaczących artykułów opisujących to zagadnienie - dr. Csabe Polgára. W pierwszym przedstawianym badaniu [3], do którego nabór prowadzony był w latach 1998-2004, poddano randomizacji 258 pacjentek z nisko, miejscowo zaawansowanym rakiem gruczołowym piersi (stopień I i II) po zabiegu chirurgicznym z negatywnymi marginesami wycięcia oraz bez dodatkowych, histopatologicznych czynników ryzyka wznowy. 129 pacjentek otrzymało standardoweleczenie uzupełniające czyli napromienianie całej piersi (WBI - whole breast irradiation) metodą pól tangencjalnych przy użyciu aparatów kobaltowych $(n=29)$ i akceleratorów liniowych (fotony 9-16 MeV) do sumarycznej dawki fizycznej 50 Gy natomiast 128 zakwalifikowano do częściowego napromieniania piersi (PBI - partial breast irradiation) na lożę po guzie z marginesem wynoszącym $2 \mathrm{~cm}$, z czego 80 chorych leczonych było metodą śródtkankowej brachyterapii wysokiej mocy dawki (HDR - high-dose rate) w schemacie frakcjonowania 7 x 5,2 Gy (b.i.d. - łac. bis in die - dwa razy dziennie), a 40 pacjentek otrzymało terapię elektronami 6-15 MeV (mediana dawki 50 Gy, $2 \mathrm{~Gy} /$ frakcję). Mediana obserwacji wynosiła 10,2 lat, a ocenie kosmetycznej poddano 256 chorych (jedna pacjentka nie otrzymała WBI ze względu na rozpoznanie rozsiewu choroby przed rozpoczęciem radioterapii, 2 pacjentki nie poddawały się kontroli po leczeniu). Ocena efektu kosmetycznego dokonywana była na każdej wizycie kontrolnej przez lekarza za pomocą subiektywnej 4-punktowej skali Harvardzkiej [4] (tłum. własne):

- Efekt doskonały - leczona pierś prawie identyczna jak pierś nieleczona.

- Efekt dobry - leczona pierś różni się nieco od piersi nieleczonej.

- Efekt zadowalający - leczona pierś wyraźnie różni się od nieleczonej, ale nie jest poważnie zniekształcona.

- Efekt słaby - leczona pierś jest poważnie zniekształcona.

Wynik doskonały lub dobry uzyskało 81\% w ramieniu PBI i 63\% w ramieniu WBI, różnica ta była istotna statystycznie ( $\mathrm{p}<\mathrm{0}, 01)$. W grupie PBI efekt doskonały lub dobry uzyskało 85\% pacjentek po brachyterapii HDR i $72,5 \%$ po leczeniu elektronami $(p=0,97)$, podczas gdy w grupie WBI taki efekt uzyskano u $67 \%$ chorych przy użyciu fotonów 6-9 MV i 48\% przy użyciu kobaltu ( $\mathrm{p}=0,08)$. Wykluczając z analizy pacjentki z elektronowym PBI i WBI z użyciem aparatów kobaltowych, również znacznie więcej pacjentek leczonych brachyterapią HDR miało doskonały lub dobry efekt kosmetyczny w porównaniu do tych, które leczone były metodą WBI fotonami 6-9 MV (85\% vs 67\%; p <0,01). Należy zaznaczyć, że między ramionami WBI i PBI nie uzyskano istotnej statystycznie różnicy w zakresie wznowy miejscowej (odpowiednio 6 i 7 wznów miejscowych, $p=$ 0,7669). W drugim prezentowanym badaniu, również randomizowanym, porównywano powikłania późne 
i efekt kosmetyczny u pacjentek powyżej 40 roku życia także z nisko, miejscowo zaawansowanym rakiem gruczołowym piersi po zabiegu chirurgicznym (pTis, pT1-2, pNo, pNmi) z marginesami wycięcia $\geq 2 \mathrm{~mm}$ [5]. W pierwszym ramieniu badania pacjentki zakwalifikowano do uzupełniającej teleradioterapii WBI (pola tangencjalne) z użyciem fotonów 4-18 MeV do dawek 50-50,2 Gy podanych w 25-28 frakcjach z następowym podwyższeniem dawki na lożę po guzie w dawce 10 Gy w 5 frakcjach z użyciem elektronów $(\mathrm{n}=551)$, natomiast w drugim ramieniu pacjentki leczone miały być metodą przyśpieszonego częściowego napromieniania piersi (APBI - accelerated partial breast irradiation) przy użyciu śródtkankowej brachyterapii $(\mathrm{n}=663)$. W pierwszym ramieniu pełną dawkę leczenia otrzymało $98 \%$ chorych $(n=541)$. W drugim ramieniu pacjentki otrzymały brachyterapię HDR w schemacie frakcjonowania 8 x 4 Gy (b.i.d.) (n = 451) i 7 x 4,3 Gy (b.i.d.) (n =59) lub brachyterapię pulsacyjną PDR (pulse-dose rate) do dawki 50 Gy podawanej w pulsach o,6 - o,8 Gy co 1 godzinę $(n=119)$. We wcześniejszej pracy autorzy pokazali, że między obiema grupami nie ma różnic w zakresie przeżycia wolnego od choroby oraz przeżyć odległych między badanymi ramionami [6]. Mediana obserwacji obu grup wynosiła 6,6 lat. Także w tym badaniu efekt kosmetyczny oceniano za pomocą skali Harvardzkiej, jednak oceny dokonywał zarówno lekarz jak i pacjentka. Ocena wykonywana była wyjściowo na pierwszej kontroli po 3 miesiącach od zakończenia terapii, następnie po roku, 3 i 5 latach po leczeniu W ocenie samych pacjentek efekt kosmetyczny doskonały lub dobry wyjściowo uzykało 92\% leczonych zarówno w ramieniu APBI jak i WBI $(\mathrm{p}=0,84)$ po roku odpowiednio 92\% i 91\% $(\mathrm{p}=0,53)$ i odsetek ten nie zmienił się już w czasie kolejnych kontroli (po 3 latach $\mathrm{p}=0,55$; po 5 latach $\mathrm{p}=0,62$ ). Natomiast w ocenie lekarzy odsetek efekt kosmetyczny doskonały lub dobry nie zmieniał się w trakcie kontroli i od początku wynosił 93\% dla grupy APBI i 90\% dla WBI - tu również nie uzyskano istotności statystycznej między badanymi grupami (odpowiednio dla kolejnych kontroli: $p=0,13 ; p=0,10 ; p=0,065 ; p=0,12$ ). Istotność statyczną uzyskano natomiast porównując odsetki tylko wyników doskonałych obu ramionach. W grupie samooceny dla APBI i WBI wynosiły odpowiednio 44\% i 32\% na pierwszej kontroli (p = 0,0001), 44\% i 31\% po roku (p < o,o001), 43\% i 30\% po 3 latach (p < o,0001) oraz 44\% i 31\% po 5 latach (p = 0,0001). W grupie ocenianej przez lekarzy wyniki były dość podobne i wynosiły odpowiednio 40\% i 30\% na pierwszej kontroli ( $\mathrm{p}=$ o,0005), 39\% i 31\% po roku (p < 0,0024), 39\% i 30\% po 3 latach (p = o,00o8) oraz 40\% i $30 \%$ po 5 latach ( $\mathrm{p}=0,0012)$. W badaniu zaobserwowano także statystycznie wyższe ryzyko wystąpienia późnych powikłań skórnych w stopniu 2 i 3 wg RTOG w grupie WBI co jednak wg autorów prawdopodobnie nie ma przełożenia na efekt kosmetyczny - ten po mimo faktu, że wydaje się być lepszy w grupie APBI to przewaga ta widoczna jest już od pierwszej oceny po leczeniu, co więcej efekt w obu grupach pozostaje stabilny, może to wskazywać np. na dominujący wpływ pierwotnego leczenia chirurgicznego na kosmetykę piersi.

\section{Rak przedsionka nosa}

W trakcie sesji poświęconej brachyterapii regionu głowy i szyi prezentowane było wyjątkowo ciekawe holenderskie doniesienie dotyczące leczenia raka płaskonabłonkowego przedsionka nosa, który jest chorobą bardzo rzadką. Warto wspomnieć, że jedno z najważniejszych doniesień dotyczących leczenia tego rozpoznania przy użyciu chirurgii i/lub teleradioterapii pochodzi również z Holandii i oparte jest na 174 historiach chorób. W opracowaniu tym ustalono współczynnik zachorowalności na poziomie o,32 przypadków na 100 ooo mieszkańców [7]. Między innymi dlatego tak duże wrażenie robi liczebność grupy w tej pracy retrospektywnej - aż 102 chorych leczonych było przez dr. Czerwinskiego i wsp. za pomocą samodzielnej śródtkankowej $(n=77)$ i kontaktowej $(n=25)$ brachyterapii HDR w latach 1992-2015 [8]. Zaawansowanie miejscowe nowotworów wg kalsyfikacji Wang’a ograniczone było do stopni T1 i T2 odpowiednio u 82 i 20 pacjentów, natomiast 3 chorych miało również przerzuty do węzłów chłonnych szyi w momencie rozpoznania i otrzymali oni leczenie chirurgiczne z uzupełniającą teleradioterapią. Pacjenci i przed rokiem 2010 (n=60) leczeni byli w technice 2D (planowanie na podstawie rekonstrukcji dwuwymiarowej) i otrzymali dawki pomiędzy 42 a 54 Gy w dawkach frakcyjnych od 3 do 4,7 Gy b.i.d 7 dni w tygodniu, natomiast od 2010 roku wprowadzono technikę 3D (planowanie na podstawie rekonstrukcji trójwymiarowej) i stosowano dawkę 49 Gy we frakcjach po 3,5 Gy b.i.d również bez przerw. Planowanie w obu przypadkach odbywało się na izodozę 100\% obejmującą GTV (gross tumor volume) czyli objętość guza, natomiast izodoza 85\% obejmować miała CTV (clinical target volume) - w tym przypadku GTV z marginesem $1 \mathrm{~cm}, \mathrm{w}$ którym zakładano potencjalne, niewidoczne w badaniu obrazowym występowanie nowotworu. Przy użyciu brachyterapii uzyskano świetne 
wyniki leczenia - pięcioletnia kontrola miejscowa nowotworu w całej grupie wynosiła 95\%, a w grupie leczonej po 2010 roku aż 100\% przy medianie obserwacji wynoszącej 42 miesiące. Tak dobry rezultat pokazuje jednoznacznie, że często okaleczająca chirurgia nie jest konieczna w przypadku miejscowo zaawansowanego raka przedsionka nosa. Badacze postanowili jednak sprawdzić jak sami pacjenci oceniają funkcjonalność oraz efekt kosmetyczny po leczeniu brachyterapią. W tym celu wykorzystali kwestionariusz NAFEQ (Nasal Appearance and Function Evaluation Questionnaire) pierwotnie używany przez chirurgów do oceny efektu operacji rekonstrukcyjnych, który został rozesłany pocztą do 42 pacjentów leczonych między styczniem 2005 a grudniem 2015. Ankieta zawiera czternaście pytań i składa się dwóch części, w tym siedmiu pytań dotyczących funkcji nosa i siedmiu pytań do oceny zadowolenia z wyglądu nosa. Pacjenci oceniają swoje zadowolenie na 5-punktowej skali Likerta [9] (Tabela 1.)

Odpowiedzi udzieliło 31 pacjentów (73\%). Uzyskane średnie wyniki w całej grupie to 3,7 punktu dla funkcji nosa oraz 4 punkty dla wyglądu nosa (na 5 możliwych punktów). Odpowiedzi o najniższej liczbie punktów dla każdej z kategorii dotyczyły problemu zatkania nosa przez stwardniałą wydzielinę ('średnia 2,5 z 5) i zadowolenia z wyglądu skrzydełek nosa (średnia 3,8 z 5). Ze względu na tak dobre wyniki oraz wysoką satysfakcję pacjentów autorzy tego doniesienia rekomendują, aby brachyterapia w raku płaskonabłonkowym przedsionka nosa była leczeniem pierwszego wyboru.

Tabela 1. Kwestionariusz dotyczący wyglądu i funkcji nosa

(NAFEQ - Nasal Appearance and Function Evaluation Questionnaire)[9] (tłum. własne).

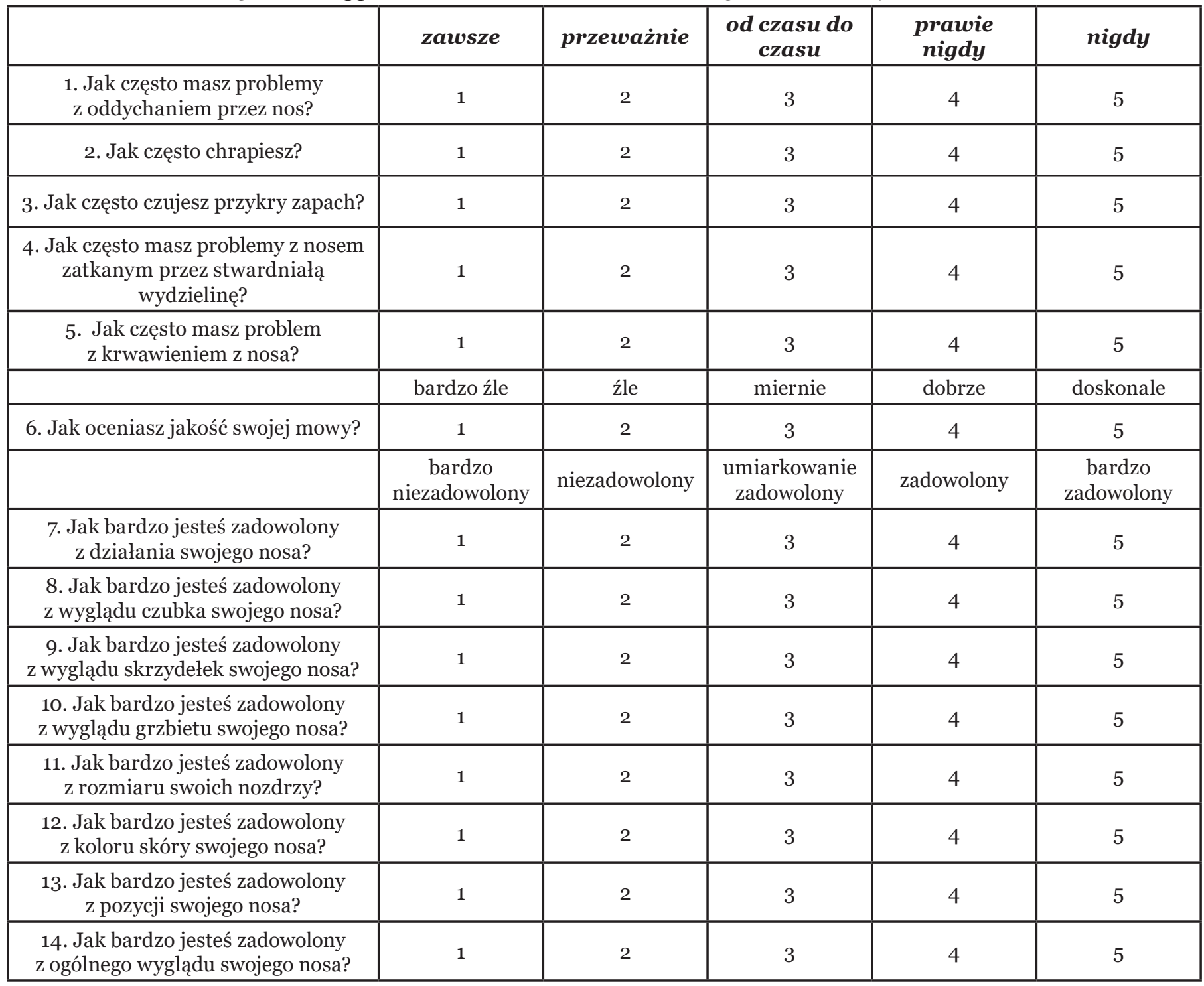




\section{Finansowanie/ Financial suport}

Praca finansowana w ramach grantu wewnętrznego Wielkopolskiego Centrum Onkologii nr 2/2018

\section{Piśmiennictwo / References}

[1] Skowronek J. Current status of brachytherapy in cancer treatment - short overview. $J$ Contemp Brachytherapy. 2017;9(6):581-589. doi:10.5114/jcb.2017.72607

[2] Barnett GC, West CM, Dunning AM, et al. Normal tissue reactions to radiotherapy: towards tailoring treatment dose by genotype. Nat Rev Cancer. 2009;9(2):134-142. doi:10.1038/nrc2587

[3] Polgár, Csaba et al. Breast-conserving therapy with partial or whole breast irradiation: Ten-year results of the Budapest randomized trial. Radiotherapy and Oncology, Volume 108, Issue 2, 197 - 202 doi: 10.1016/j.radonc.2013.05.008

[4] Jay R. Harris; Martin B. Levene; Goran Svensson; Samuel Hellman. Analysis of cosmetic results following primary radiation therapy for stages I and II carcinoma of the breast. International Journal of Radiation Oncology*Biology*Physics Volume: 5 Issues: 2 257-261 doi: 10.1016/0360-3016(79)90729-6

[5] Csaba Polgár, Oliver J Ott, Guido Hildebrandt, Daniela Kauer-Dorner, Hellen Knauerhase, Tibor Major et al. Late side-effects and cosmetic results of accelerated partial breast irradiation with interstitial brachytherapy versus whole-breast irradiation after breast-conserving surgery for low-risk invasive and in-situ carcinoma of the female breast: 5 -year results of a randomised, controlled, phase 3 trial. Lancet Oncol. 2017 Feb;18(2):259-268. doi: 10.1016/S1470-2045(17)30011-6

[6] Vratislav Strnad, Oliver J Ott, Guido Hildebrandt, Daniela Kauer-Dorner ,Hellen Knauerhase, Tibor Major et al. 5-year results of accelerated partial breast irradiation using sole interstitial multicatheter brachytherapy versus whole-breast irradiation with boost after breast-conserving surgery for low-risk invasive and in-situ carcinoma of the female breast: a randomised, phase 3, non-inferiority trial. Lancet. 2016 Jan 16;387(10015):229-38. doi: 10.1016/So140-6736(15)00471-7

[7] Agger A, von Buchwald C, Madsen AR, et al. Squamous cell carcinoma of the nasal vestibule 19932002: A nationwide retrospective study from DAHANCA. Head Neck 2009;31:1593- 1599. doi: 10.1002/ hed.21132

[8] Michal D. Czerwinski, Ruud G.H.van Leeuwen, Johannes H.A.M. Kaanders, Ellen M.Zwijnenburg, Djoeri Lipman et al. Image Guided Brachytherapy for Cancer of the Nasal Vestibule: Achieving High Locoregional Control While Preserving Cosmesis, International Journal of Radiation Oncology*Biology*Physics Volume 103, Issue 4, 913 - 921 doi: 10.1016/j.ijrobp.2018.11.018

[9] Moolenburgh, S.E. et al. Validation of a questionnaire assessing patient's aesthetic and functional outcome after nasal reconstruction: the patient NAFEQ-score. Journal of Plastic, Reconstructive \& Aesthetic Surgery, Volume 62, Issue 5, 656 - 662 doi: 0.1016/j.bjps.2007.07.024. 